\title{
The radiometric framework of the Solutrean and Badegoulian sequence of Le Cuzoul de Vers (Lot, France): critical view and new data
}

Le cadre radiométrique de la séquence solutréo-badegoulienne du Cuzoul de Vers (Lot, France) : lecture critique et compléments

\section{Sylvain Ducasse, Jean-Marc Pétillon and Caroline Renard}

\section{OpenEdition}

Journals

\section{Electronic version}

URL: http://journals.openedition.org/paleo/3008

DOI: 10.4000/paleo.3008

ISSN: 2101-0420

\section{Publisher}

SAMRA

\section{Printed version}

Date of publication: 28 December 2014

Number of pages: $37-58$

ISSN: $1145-3370$

Electronic reference

Sylvain Ducasse, Jean-Marc Pétillon and Caroline Renard, «The radiometric framework of the Solutrean and Badegoulian sequence of Le Cuzoul de Vers (Lot, France): critical view and new data », PALEO [Online], 25 | 2014, Online since 09 June 2016, connection on 07 July 2020. URL : http:// journals.openedition.org/paleo/3008; DOI : https://doi.org/10.4000/paleo.3008

This text was automatically generated on 7 July 2020 . 


\title{
The radiometric framework of the Solutrean and Badegoulian sequence of Le Cuzoul de Vers (Lot, France): critical view and new data
}

\author{
Le cadre radiométrique de la séquence solutréo-badegoulienne du Cuzoul de Vers \\ (Lot, France) : lecture critique et compléments
}

Sylvain Ducasse, Jean-Marc Pétillon and Caroline Renard

It is a pleasure for us to thank Jean Clottes and Jean-Pierre Giraud for entrusting us with the different analyses and reevaluations of Cuzoul de Vers. We also extend warm thanks to Pierre Chalard for his support and advice, as well as to the Service Régional de l'Archéologie de MidiPyrénées for funding some of the dates presented here (Artémis program).

Two of the eleven measurements were funded by a grant from the Fondation des Treilles obtained by one of us (JMP). A big thank you to Bernard Marty and Olivier Gaiffe who facilitated access to the antler industries curated in the regional depot in Toulouse, as well as to JeanChristophe Castel for his help in selecting the Solutrean remains. We also wish to thank François Lacrampe-Cuyaubère, docteur ès Data DeskTM and Olivier Ferullo for access to certain comparative data. The acquisition of these data owes a lot to the logistic help of Laurent Brou (for the loan of the drill bits) and Didier Galop (for his hospitality in the GEODE laboratory and the loan of material), and we sincerely thank them. We also extend thanks to the dating teams from the Lyon (CDRC), Saclay (CEA) and Oxford (ORAU) laboratories. We are grateful to Carolyn Barshay-Szmidt, Emmanuel Discamps and the two anonymous reviewers for their critical comments which considerably improved the quality of this article.

\section{Introduction}

1 Cuzoul de Vers Rock shelter (Lot) was discovered in 1982 and excavated until 1986 under the direction of Jean Clottes and Jean-Pierre Giraud. It is located at the foot of a 
south-facing limestone cliff, at the edge of the RN 653, which separates the shelter from the Lot River, situated about 30 metres from the back of the shelter. During the course of a 5 year rescue excavation program, this site yielded a sedimentary record spanning all or part of the first half of the Last Glacial Maximum (DMG; sensu Mix, Bard, Schneider 2001, MARGO project 2009). In archaeological and sedimentary terms, this reference stratigraphy is made up of three layers attributed to the Upper Solutrean (c. 31 to 29), overlain by 27 layers with lithic and bone material ascribed to the Badegoulian, from the very beginning of this culture (Early Badegoulian: 1. 27 to 22) until the "classical" phase, from a historiographical point of view (Recent Badegoulian with raclettes: 1. 21 to 1; Clottes and Giraud 2012).

At the end of 2012, the site monograph was published, representing multidisciplinary studies carried out over a period of nearly 15 years (Clottes et al. dir., 2012). Due to the abundance and diversity of the remains (lithic industry, osseous industry, personal ornaments, fauna and microfauna, portable art, pigments, human remains, etc.), specialized analyses were planned and conducted from the end of the 1990s onwards, following approaches classically applied (Clottes and Giraud 2012). These studies led to interdisciplinary approaches and laid the foundations for new reflections on the socioeconomic trajectory of societies known during the first half of the LGM in present-day France (Ducasse and Renard 2012).

3 It also provided the opportunity to critically assess the available archaeological data, and to initiate indispensable complementary analyses. Among these complements, the reevaluation of the archaeostratigraphic framework appeared to be vital, given the complexity of the infilling, as shown by the existence of inter-layer refits and associations of the lithic (Ducasse 2010) and osseous industries (Le Guillou 2012), the vertical distribution of certain human remains ascribed to the same individual (HenryGambier and Villotte 2012), or some of the ambiguous stratigraphic links between different hearth structures (Fourment and Giraud 2012). It is nonetheless important to point out that these different markers do not represent post-depositional disturbances, but seem, above all, to denote that the archaeological levels are not in keeping with the sedimentary divisions defined at the excavation (cf. below for the Solutrean levels) and imposed by the type of infilling (strong lateral and vertical variations of the sedimentological facies) and by the topographic constraints of the fieldwork (Clottes and Giraud 1989). In addition, the new radiometric markers obtained during the early 2000s (14C by AMS: Oberlin and Valladas 2012) considerably modified the framework defined during the course of the 1980s (classical method ${ }^{3}$ : Clottes and Giraud 1989). These new Badegoulian dates were older and closer together and also presented overlaps between certain cultural phases as well as several inversions and/or chronological anomalies.

4 In consequence, and in parallel with a fundamental but very time-consuming critical taphonomic study ${ }^{4}$, a revision of the available radiometric framework appeared vital.

5 The main objectives of this work were to (1) test the older and more closely grouped AMS dates, (2) to try to gauge the extent and the chronological position of each of the main documented occupation phases (Upper Solutrean /Early Badegoulian/Recent Badegoulian) and in doing so, (3) to more accurately identify the "transition" phases from one to the other and/or any possible gaps in site occupation. Our contribution is, as of yet, preliminary, but it extends the results obtained in the scope of the monograph by proposing a critical interpretation of the new $14 \mathrm{C}$ measurements. These 
measurements were taken from samples selected following a simple but systematic protocol that backs up the value of the obtained results and allows for an ulterior critical analysis of our interpretations (cf. infra: technologically identified antler waste chrono-culturally characteristic of the Badegoulian; anatomically and/or speciesdetermined faunal remains selected according to strictly defined location criteria for the Solutrean; in all cases the exact stratigraphic position of the pieces is known and can be verified).

\section{Archaeosequence versus 14C dates: problems and questions raised}

6 The nine excavation seasons brought to light a differentially preserved site stratigraphy over two meters thick (Clottes and Giraud 1989, 2012). The construction of the road running alongside the Lot River and the ensuing developments aiming to improve traffic visibility truncated the sequence at the top of the infilling (i.e., l.s 1 to 4 : only 2 to $10 \mathrm{~m}^{2}$ conserved). In addition, some of the lowest levels, uncovered over more extensive surfaces (i.e., layer 13 to 31: generally excavated over more than $30 \mathrm{~m}^{2}$ ), are partly sealed by the present-day RN 653. Although most of the identified layers thus provide different levels of information, the archaeological material allows for the identification of diachronic variations which clearly cut through any possible representativeness problems linked to these different constraints. From the human occupations attributed to the end of the Solutrean (op. cit.; Renard 2008 and 2012), this exceptionally broad sequence allows for the observation of the development and evolution of new typo- and techno-economic standards introduced during the Badegoulian north of the Pyrenees. The identification of an occupation phase contemporaneous with the earliest Badegoulian was one of the major attractions of this site, as the development of this phase at Cuzoul de Vers has no equivalent throughout Western Europe.

7 Several dates were obtained very early on and as the excavation advanced, in order to provide accurate data concerning the chronological position of each level and to allow for comparisons with the rare previously dated stratigraphies from this period (Laugerie-Haute: Evin, Marien, Pachaudi 1976; Abri Fritsch: Evin, Marien, Pachaudi 1978).

\section{The classical method}

8 Two series of dates were obtained using the classical method; one in 1984 (two dates for the Recent Badegoulian, one date for the Early Badegoulian) and the other in 1985 (two dates for the Recent Badegoulian, one date for the Early Badegoulian and one date for the Upper Solutrean discovered in 1984), all by the Gif-sur-Yvette laboratory (tab. 1, $\mathrm{n}^{\circ}$ 1 to 7; Delibrias and Guillier 1988). On account of the marked fragmentation of the bone remains and their low collagen content, the remains selected for dating correspond to batches of bone fragments of "bulk samples" (Oberlin and Valladas 2012). Apart from 1. $3^{5}$, the obtained results fit perfectly into the radiometric framework that was then in the process of being defined for these cultural phases (fig. 1A). These data are much more exact than the measurements available for Laugerie-Haute and the Fritsch Rock 
shelter and are remarkably similar to those from the Casserole Rock shelter sequence, a site excavated at the beginning of the 1990s (Detrain et al. 1993 and1994).

Although this sequence of dates is very coherent, their main interest is to provide landmarks for the overall chronological range of the human occupations from Cuzoul de Vers. In theory, they only provide general markers, representative of certain "selected morsels" from the stratigraphy $(1.5,13,20,23 / 24$ and 30, i.e., the top, the centre and the base of the Recent Badegoulian sequence, the top of the Early Badegoulian and the base of the Upper Solutrean $\left.{ }^{6}\right)$. After calibration, the absence of overlap between the Upper Solutrean and the Early Badegoulian, as well as the hiatus observed between the Early and recent phases of the Badegoulian (which match the observed sequence at Casserole Rock shelter: fig. 1A) cannot thus be interpreted from an archaeological viewpoint: these "grouping phenomena", accentuated by sampling modalities (bulk bone samples), probably result more from these choices than from any real occupational discontinuity.

Figure 1- Graphic summary of the chronological framework established at Cuzoul de Vers between 1984 and 2001 (from Clottes and Giraud 1989; Oberlin and Valladas 2012). A: radiometric dating of I. 3, 5, 13, 20 (Recent Badegoulian), 23, 24 (Early Badegoulian) and 30 (Upper Solutrean) compared to radiometric dates from the Casserole (Detrain et al. 1993), Fritsch and Laugerie Haute rockshelters (Evin et al.1976 and 1978). B: Discrepancies between the beta counting method (on the left) and the AMS method (on the right) at Cuzoul de Vers.

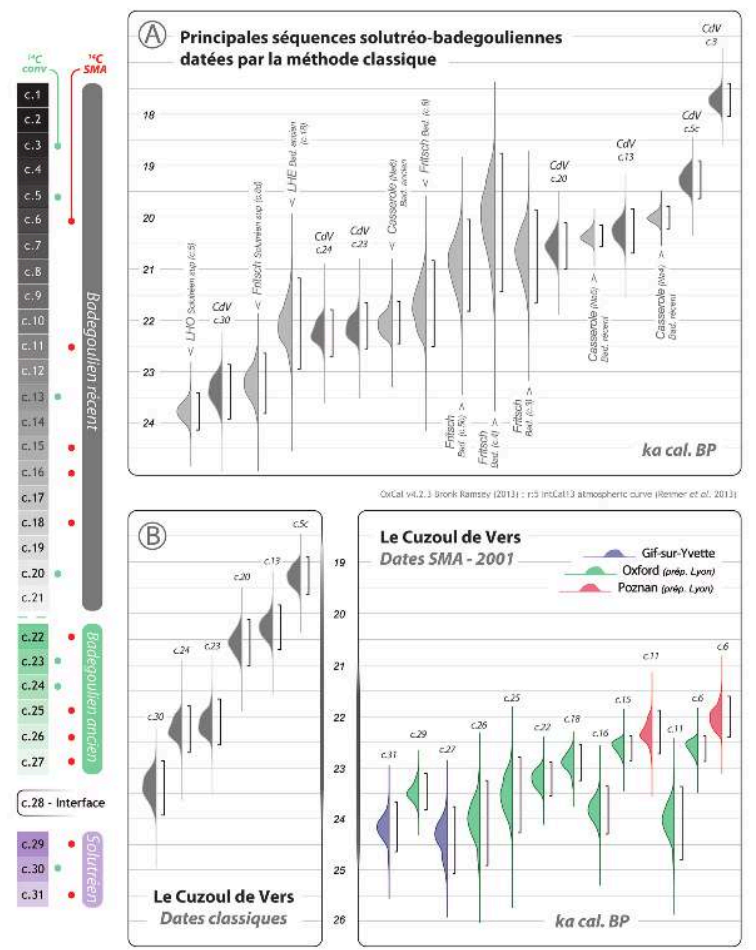

\section{What the AMS dates changed}

10 At the end of the 1990s, the preparation of the publication project provided the opportunity to complete these data and to refine the temporal sequencing of the different phases of site occupation. Thirteen additional analyses were thus carried out, bringing the total number of dated layers to 18 (tab. $1, n^{\circ} 8$ to $20: 13$ dates for 11 layers). 
By cumulating the different series of dates obtained between the middle of the 1980 s and the beginning of the 2000s (Oberlin and Valladas 2012), the available corpus covers a large part of the sequence as it concerns almost half of the levels attributed to the Recent Badegoulian (9 layers out of $21^{7}$ ) and all those related to the Upper Solutrean and the Early Badegoulian (1. 22 to 31). These new measurements benefitted from the technical developments linked to Accelerator Mass Spectrometry (AMS: Valladas et al. 2001), and theoretically result from more accurate sampling strategies (one date $=\mathrm{a}$ single remain; no "average" dates), and consequently guarantee more accurate results. The dated samples correspond to shafts from average-sized ungulates (nondetermined, but related to the reindeer or ibex) selected by Jean-Christophe Castel after the archaeozoological analysis (Castel 1999, 2003 and 2010). Two samples were entrusted to the Gif-sur-Yvette laboratory, already in charge of the first series of dates (tab. 1: 1.27 and 31). The Lyon laboratory looked after the preparation of another 11 pieces to be dated (purification and decontamination treatments), and then sent the samples to Oxford (nine cases) and Poznan (two cases) so that the measurements could be conducted.

(1) previously available dates (fig. 1B). The most obvious of these is the ageing of the radiometric context: once the dates are calibrated to two sigma, the end of the Badegoulian occupations could be established at $19 \mathrm{ka}$ cal BP with the classical method (l. 5: $15980 \pm 150 \mathrm{BP}$, or 19640-18910 cal. BP), whereas the AMS dates establish this same limit around $21.5 \mathrm{ka}$ cal. BP (1. 6: $18180 \pm 170 \mathrm{BP}$, or 22417-21614 cal. BP). In addition, these data considerably reduce the chronological span of the Cuzoul de Vers occupations, varying from 5,000 years (classical 14C: from 24 to $19 \mathrm{ka} \mathrm{BP}$ ) to 3,500 years (14C by AMS: from 25 to $21.5 \mathrm{ka}$ $\mathrm{BP})$. Finally, this double ageing/narrowing effect is completed by the disappearance of the hiatuses induced by the first two dating series (fig. 1B, on the left).

Table 1- Results of classic ( $n^{\circ} 1$ to 7 ) and AMS dates ( ${ }^{\circ} 8$ to 20$)$ carried out between 1984 and 2001 (after Clottes and Giraud 1989; Oberlin and Valladas 2012). OTM = Medium-Sized Ungulate. Information related to the location of dated-AMS samples was provided by J.-C. Castel. Calibration was conducted with the OxCal program (v4.2.3: Bronk Ramsey 2013) using the IntCal13 calibration curve (Reimer et al. 2013).

\begin{tabular}{|c|c|c|c|c|c|c|c|c|c|}
\hline & Réf. échantillon & Méthode & Couche & Attribution & Matériau & Type d'échantillon & Code laboratoire & Age BP & 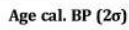 \\
\hline 1 & Carrés G2-3 / F2 & Class. & 3 & Badegoulien récent & os & Lot d'esquilles & Gif-6372 & $14560 \pm 130$ & $18050-17409$ \\
\hline 2 & Carrés E3-4 & Class. & $5 c$ & Badegoulien récent & Os & Lot d'esquilles & Gif-6638 & $15980 \pm 150$ & $19640-18910$ \\
\hline 3 & Carrés B2-4 & Class. & 13 & Badegoulien récent & Os & Lot d'esquilles & Gif-6371 & $16800 \pm 170$ & 20704-19840 \\
\hline 4 & Carrés E3-4 & Class. & 20 & Badegoulien récent & os & Lot d'esquilles & Gif-6797 & $17050 \pm 170$ & 21014-20115 \\
\hline 5 & ind. & Class. & 23 & Badegoulien ancien & os & Lot d'esquilles & Gif-6370 & $18300 \pm 200$ & $22554-21663$ \\
\hline 6 & ind. & Class. & 24 & Badegoulien ancien & Os & Lot d'esquilles & Gif-6798 & $18400 \pm 200$ & $22701-21796$ \\
\hline 7 & ind. & Class. & 30 & Solutréen supérieur & Os & Lot d'esquilles & Gif-6699 & $19400 \pm 210$ & $23915-22860$ \\
\hline 8 & "Vrac" & SMA & 6 & Badegoulien récent & Os & Diaphyse OTM & OxA-10955 (Lyon-1674) & $18730 \pm 110$ & $22889-22383$ \\
\hline 9 & "Vrac" & SMA & 6 & Badegoulien récent & Os & Lot de diaphyses OTM & Poz-1594 (Lyon-1962) & $18180 \pm 170$ & $22417-21614$ \\
\hline 10 & Carré F2 & SMA & 11 & Badegoulien récent & os & Diaphyse OTM & OxA-10903 (Lyon-1675) & $19970 \pm 270$ & $24818-23380$ \\
\hline 11 & Carré F2 & SMA & 11 & Badegoulien récent & Os & Lot de diaphyses OTM & Poz-1595 (Lyon-1963) & $18480 \pm 180$ & $22742-21888$ \\
\hline 12 & Carrés B2 ou B3 & SMA & 15 & Badegoulien récent & os & Diaphyse ОTM & OxA-10974 (Lyon-1676) & $18730 \pm 100$ & 22871-22391 \\
\hline 13 & Carré C3 & SMA & 16 & Badegoulien récent & os & Diaphyse OTM & ОхA-10975 (Lyon-1677) & $19800 \pm 190$ & $24310-23375$ \\
\hline 14 & Carré E5 & SMA & 18 & Badegoulien récent & Os & Diaphyse OTM & OxA-11118 (Lyon-1681) & $19020 \pm 110$ & $23262-22555$ \\
\hline 15 & Carrés D2 a 5 & SMA & $22 \mathrm{~b}$ & Badegoulien ancien & os & Diaphyse OTM & OxA-10976 (Lyon-1678) & $19280 \pm 120$ & $23563-22901$ \\
\hline 16 & Carré D3 & SMA & 25 & Badegoulien ancien & os & Diaphyse OTM & OxA-11080 (Lyon-1679) & $19540 \pm 310$ & $24285-22802$ \\
\hline 17 & Carré C4 & SMA & 26 & Badegoulien ancien & Os & Diaphyse OTM & OxA-11081 (Lyon-1680) & $19950 \pm 310$ & $24926-23261$ \\
\hline 18 & Carré C5 & SMA & 27 & Badegoulien ancien & Os & Diaphyse 0TM & GifA-101441 & $20230 \pm 240$ & $25081-23776$ \\
\hline 19 & Carré B5 & SMA & 29 & Solutréen supérieur & os & Diaphyse OTM & OXA-11220 (Lyon-1682) & $19510 \pm 110$ & $23836-23124$ \\
\hline 20 & Carré 14 & SMA & 31 & Solutréen supérieur & Os & Diaphyse OTM & GifA-101440 & $20110 \pm 180$ & $24655-23689$ \\
\hline
\end{tabular}

13 This "reorganization" is probably more in keeping with the real rhythm of the sequence of occupations, but nonetheless comprises clear overlaps between the 
different chronocultural phases (e.g., impossible to distinguish between the Upper Solutrean and the Early Badegoulian: fig. 1B, on the right; Oberlin and Valladas 2012, p. 80 ), as well as several inversions which raise problems even after the calibration of the measurements (e.g., l. 11 and 16).

\section{Classical dates versus $14 \mathrm{C}$ by AMS: For a disjointed use}

The narrowing of the timespan of the dates is thus partly due to the conjunction of the ageing of all the Badegoulian dates and the relative stability of the radiometric dates obtained for the Upper Solutrean (between 23.9 and $22.8 \mathrm{ka}$ cal. BP for classical $14 \mathrm{C}$ and between 24.6 and $23 \mathrm{ka}$ cal. BP for $14 \mathrm{C}$ by AMS ${ }^{8}$ ). The chronological discrepancy observed between the classical dates and the AMS dates - the latter always denoting older dates - raises comparability problems (Bryant et al. 2001; Geneste 2002, p. 31; d'Errico, Sanchez Goni, Vanhaeren 2006: figure 5, p. 274). In theory, this discrepancy is explained by improved (1) sampling strategies and (2) treatment techniques and methods of the samples to be dated. As far as the Badegoulian and its chronological margins are concerned, several recent reevaluations illustrate the recurrence of this discrepancy, which raises questions as to the conjoined use of the results issued from these two types of measurements, with no distinction or discussion. (e.g., for the lower Magdalenian from Gandil Rock shelter: Ladier 2000, p. 197-198; Langlais 2010; for the Badegoulian from the open-air site of Lassac: Pétillon and Ducasse 2012; Sacchi, Brulé, Ducasse in press). Given these technical and methodological elements, as well as the repetition of the phenomenon for the west European LGM, we decided to favour the AMS dates, which are increasingly numerous for this area and time (e.g., Chauvière et al. 2008; Debout et al. 2012; Ducasse et al. 2011; Ducasse and Renard dir. 2014; Hinguant and Biard 2013; Primault et al. 2007; Roque et al. 2001).

\section{What about comparability between laboratories?}

The question of the comparability of the $14 \mathrm{C}$ results obtained in different laboratories has been raised on numerous occasions ${ }^{9}$, and in so far as this difference is implicitly linked to potential variability in practices (type of pretreatments, use of different sample standards, etc.; see for example Scott 2003, Scott, Cook, Naysmith 2007 and 2010a and b). At the scale of the AMS measurements made at Cuzoul de Vers in the scope of the monograph (fig. 1B, on the right), at first glance, this question appears to be legitimate: the dating of 1.6 and 11 shows for example a clear discordance between the results obtained at Poznan (more recent) and Oxford (older), whereas the dates obtained at Gif-sur-Yvette yielded (1) the oldest date for the Upper Solutrean (1. 31) while the techno-economic and taphonomic analyses show the coherence of the level c. 29-30-31 (Renard 2012; Fourment and Giraud 2012 and infra) and (2) one of the oldest Badegoulian dates (1. 27: 20230 $\pm 140 \mathrm{BP}$, or 25081-23776 cal. BP), which is similar to that of 1.31 (20110 $\pm 180 \mathrm{BP}$, or $24655-23689 \mathrm{cal}$. BP) and earlier than that of 1.29 conducted at Oxford (19510 $\pm 110 \mathrm{BP}$, or $23836-23124 \mathrm{cal}$. BP).

16 Actually, in each case, several elements enable us to rule out the problem of comparability between the different laboratories. First of all, in our opinion, both dates obtained at Poznan (l. 6 and 11) must be considered with caution - or discarded - given the types of samples dated, corresponding to bulk bone samples (Oberlin and Valladas 2012, p. 79) ${ }^{10}$. Thus, the lack of accuracy of the results obtained and the ageing effect in 
comparison to the data acquired at Oxford (particularly for 1. 6) could be explained from a methodological viewpoint, as the measurements carried out at Poznan laboratory are average ages. Subsequently, if the result obtained by Gif-sur-Yvette for 1 . 27 appears to be incoherent, the same observation could be applied to 1.26 (even 25), dated by the Oxford laboratory, using the same type of bone remains gathered from a similar zone (tab. 1: squares $\mathrm{C} 4$ and $\mathrm{C} 5$ ). In this case, the ageing of the results (which are moreover, not very accurate: standard deviations between \pm 240 and \pm 310 ) could be related to stratigraphic disturbances that remain to be defined. Lastly, before making any conclusions as to the inaccuracy of the date obtained by Gif- sur-Yvette for 1.31 (suggested in Ducasse and Renard 2012, p. 461), it is appropriate to bear in mind that the very slight overlap between this result and the measurement obtained for 1.29 could be evidence of a distinct occupation episode: the existence of an underlying level, with a base characterized by a level "marked by very small burnt bones and several rare pebbles and flakes, pointing to a brief halt, at a non-determined period, contemporaneous with the Solutrean or older" (1. 32: Clottes and Giraud 2012, p. 27), must not be neglected. Until this possibility is definitively discarded - and given that it is impossible to pinpoint the exact location of the dated remain -, it appears difficult to adopt a definitive viewpoint.

\section{What about date inversions?}

17 Once we exclude the two dates analyzed at Poznan, one of the most striking differences between the classical dates and AMS dates concerns the appearance of abnormal inversions in relation to the stratigraphic order (fig. $1 \mathrm{~B}$, on the right). Whereas the use of the classical method tends to attenuate possible taphonomic problems (cf. above: "average" dates), the use of the AMS method tends to favour their appearance (one date = one remain). In this way, the Badegoulian 1.11, 16, 26 and 27 yielded incoherent dates that could not be weighted by two sigma calibration ${ }^{11}$. These measurements all range between 24.5 and $23.5 \mathrm{ka}$ cal. BP, i.e., the same interval of time as the earliest date obtained for the Upper Solutrean, and they are also characterized by very high standard deviations, ranging between \pm 190 and \pm 310 (as opposed to \pm 100 to \pm 120 for the other measurements, apart from Poznan: tab.1). Although it is still difficult to evaluate the significance of these incoherencies in the absence of an archaeostratigraphic analysis of the whole sequence, it is important to note (1) that the total range of the interval c11-c17 varied in places from 16 to $22 \mathrm{~cm}$ (in CD2-3: Fourment and Giraud 2012, p. 456), (2) that the dated remain from 1.16 was located in a "hollowed-out hearth" unearthed in CD2-3 (Ibid.) and (3) that the lithic industries from 1. 11, 16 and 27 each contain one to two pieces with Solutrean retouch with no evidence of ulterior retouch or use (Ducasse 2010, p. 34 and 197).

18 The recent commencement of reevaluation work by two of us (CR and SD), focusing on 1. 31 to 29,28 and 27 , now enables us to show that inter-layer refits linking the Solutrean level to the first Badegoulian levels (fig. 2: 2 links between c27 and c29) are extremely rare and probably only denote the existence of limited and localized disturbances, or may even be linked to stratigraphic interpretation difficulties (Clottes and Giraud 2012, p. 27). In the same way, the status of 1.28 , located at the Upper Solutrean and Early Badegoulian interface should be reassessed. 

described as "(...) almost sterile, as if the rock shelter had been abandoned for some time after the Solutrean occupations" (Clottes and Giraud 1989, p. 87). It contains remains which appear to belong to two levels during stratigraphic projections: in places they appear to be clEarly distinct from the first recorded Solutrean levels but in direct contact with the remains from 1. 27 (i.e. Early Badegoulian), and in others, they seem to be interleaved between 1.27 and 29 (i.e. Upper Solutrean, cf. infra fig. 7B). Attempts at refits and associations between these three layers confirm the "mixed" character of 1.28 , as physical links were clearly established (fig. 2) between 1.27 and 28 on one hand (four cases), and between 1.28 and 29 on the other (one case), in addition to the combined presence of several fragments of pieces with flat and invasive retouch and of several antler flakes identical to the Badegoulian antler waste presented in figure 3 ( $\mathrm{n}^{\circ} 2$ to 6; Pétillon and Averbouh 2012). In each case, several matches (lithotechnological relations) were also documented, strengthening the hypothesis of an artificial assemblage, resulting from the association of distinct chronocultural elements.

The intensification and extension of systematic inter-layer refit and association research to the most recent levels concerned (l. 11 and 15/16) will be one of the main aims of future analyses.

\section{A new series of AMS dates}

21 Thus, the coherent radiometric framework that was consistent with the data available at the time (classical 14C: Bosselin and Djindjian 1988), gives way today to an older, tighter (between 24.5 et and $22 \mathrm{ka}$ cal. BP, once the Poznan dates are removed) and much less coherent framework, with no regional or inter-regional published equivalent.

In 2011, as part of an extended study on the diversity and evolution of Badegoulian reindeer antler production methods (Pétillon and Averbouh 2012; Pétillon and Sacchi in press), two of us (JMP and SD) attempted to carry out several direct dates on antler débitage waste, in order to assess certain technological associations (débitage by percussion versus groove and splinter technique: Pétillon and Ducasse 2012). Alongside the reevaluation of ambiguous contexts (e.g., Lassac: Sacchi 2003; Reverdit: Bourdier et al. 2014; Les Harpons: Ducasse and Renard dir. 2013, p. 57-63), the construction of AMS reference dates from reliable archaeological contexts was thus initiated. In this way, the Badegoulian industries from Cuzoul de Vers, representing one of the best documented series of débitage by percussion (Pétillon and Averbouh 2012), contribute to the development of chronological markers for this method. Initially, two $14 \mathrm{C}$ measurements were entrusted to the Oxford laboratory in the aim of publishing the results quickly (Pétillon and Ducasse 2012: table 5, p 158), but the dating program was then extended to seven additional measurements when funding was granted by the ARTEMIS program in 2011. Lastly, as part of the PCR SaM and ARTEMIS 2012, four remains from 1. 29 to 31 were also dated, in order the evaluate the diachrony of the Solutrean occupations but also in order to obtain comparative "quality" data (cf. sampling strategy), as for the Badegoulian (Ducasse and Renard 2014). This extension thus provided the opportunity to combine a thematic question linked to antler

PALEO, 25 | 2014 
Badegoulian material with the radiometric reevaluation of this reference sequence for the LGM in Western Europe.

\section{Sampling strategies}

Figure 2 - Stratigraphic position of the AMS dates carried out in 2011-2013 ( 1 red circle $=1$ date) and summary of the typological and stratigraphic links throughout the sequence (after Ducasse and Renard 2012, modified).

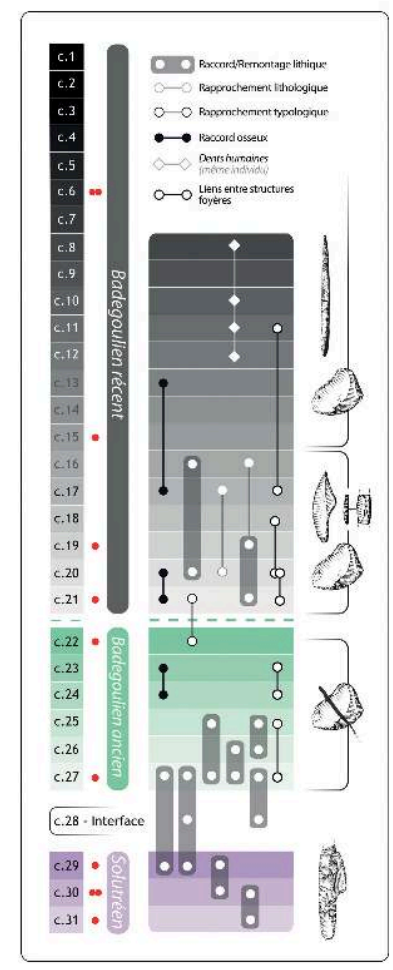

For the Badegoulian, six technical pieces were thus selected in June 2011 for a total of seven samples entrusted to the laboratories of Oxford (fig. 3, $\mathrm{n}^{\circ} 1$ and 2) and Lyon (dating at Saclay; $\mathrm{n}^{\circ} 1$ and $\mathrm{n}^{\circ} 3$ to 6). Four of these pieces correspond to percussion flakes linked to the shaping of the beam ( $\mathrm{n}^{\circ} 2$ to 5 ), and the two remaining pieces are of the base of a shed antler, transversally sectioned and bearing a flake scar $\left(n^{\circ} 1\right)$, and a splinter of compact tissue interpreted as a potential blank ( $n^{\circ} 6$; Pétillon and Averbouh 2012, p. 380). As the questions raised within the scope of the analysis of antler production are mainly centred around the Badegoulian-Magdalenian transition (Pétillon and Ducasse 2012), both the samples for Oxford laboratory were selected from the assemblages attributed to the Recent Badegoulian (tab. 2). The only criteria applied to this selection, apart from the requirement to choose coordinated pieces only, concern the surface conditions of these pieces, and the dimensions and robustness, so that they conform to the sampling methods described below. This choice focused on 1.6 and 15, which are two of the levels with the highest concentration of antler (Pétillon and Averbouh 2012, p. 365). The selection of pieces as part of the ARTEMIS program took place at the same time, but followed a different and complementary approach. As the upper part of the sequence was entrusted to Oxford, this selection focused on (1) the base of the Recent Badegoulian sequence, marked by the presence of shouldered points with original abrupt retouch (l. 16 to 21$)$ and (2) the Early Badegoulian (1. 22 to 
27), rare in the southwest of France and not very well radiometrically dated up until now (cf. supra). Thus, 1. 19, 21, 23 and 27 were chosen on account of the representativeness of each level, the typological and/or physical links established between them (fig. 2; Ducasse and Renard 2012: figure 1, p.464) ${ }^{12}$, as well as the presence of characteristic, datable, and well-positioned waste products. Lastly, in order to test - and strengthen (cf. supra) - the reliability of the radiometric framework given by several distinct laboratories, a second sample was taken from the antler base from 1 . 6 and entrusted to the Lyon/Saclay laboratories.

Table 2 - AMS dates carried out in 2011-2013 (BdR = Antler). The dates were calibrated with the OxCal program (v4.2.3: Bronk Ramsey 2013) using the IntCal13 calibration curve (Reimer et al. 2013).

\begin{tabular}{|c|c|c|c|c|c|c|c|c|}
\hline Réf. échantillon & Couche & Attribution & Matériau & Type d'échantillon & Code laboratoire & Age BP & Age cal. BP (2б) & Réf. fig. \\
\hline CZ $84 \mathrm{~K} 4 \mathrm{c} .6 \mathrm{c}^{\prime} \mathrm{n}^{\circ} 289$ & 6 & Badegoulien récent & $\mathrm{BdR}$ & Base avec négatifs d'éclats & Lyon-9074 (SacA-28341) & $18620 \pm 100$ & $22757-22290$ & fig $2 n^{\circ} 1$ \\
\hline CZ. 84 K4 c.6c' n² 289 & 6 & Badegoulien récent & $\mathrm{BdR}$ & Base avec négatifs d'éclats & OxA 24963 & $18660 \pm 100$ & $22803-22335$ & fig $2 n^{\circ} 1$ \\
\hline CZ 85 D5 c.15a n²30 & 15 & Badegoulien récent & $\mathrm{BdR}$ & Éclat de percussion & OXA 24964 & $19180 \pm 110$ & $23468-22804$ & fig $2 n^{2} 2$ \\
\hline CZ 83 D4 c.19 n n $^{\circ} 772$ & 19 & Badegoulien récent & $\mathrm{BdR}$ & Éclat de percussion & Lyon-9076 (SacA-28343) & $18590 \pm 110$ & $22757-22216$ & fig $2 n^{\circ} 3$ \\
\hline CZ $85 \mathrm{~J} 4 \mathrm{c} .21 \mathrm{c} \mathrm{n}^{\circ} 1555$ & 21 & Badegoulien récent & $\mathrm{BdR}$ & Éclat de percussion & Lyon-9075 (SacA-28342) & $18860 \pm 110$ & $23003-22460$ & fig $2 n^{\circ 5}$ \\
\hline CZ 8615 c.22a n636 & 22 & Badegoulien ancien & BdR & Bande corticale & Lyon-9077 (SacA-28344) & $18920 \pm 110$ & $23072-22489$ & fig $2 n^{\circ} 6$ \\
\hline CZ 86 D5 c.27n nº 1192 & 27 & Badegoulien ancien & BdR & Éclat de percussion & Lyon-9078 (SacA-28345) & $19150 \pm 110$ & $23446-22757$ & fig $2 n^{\circ} 4$ \\
\hline CZ 86 E5 c.29a nº 1649 & 29 & Solutréen supérieur & Os & Métatarsien de renne & Lyon-10351 (SacA-33960) & $19410 \pm 100$ & $23668-23038$ & fig $3 n^{\circ} 1$ \\
\hline CZ 8614 c.30 n²472 & 30 & Solutréen supérieur & Os & Diaphyse OTM & Lyon 10352 (SacA 33961) & $19380 \pm 100$ & $23631-23016$ & fig $3 n^{\circ 3}$ \\
\hline CZ 85 B 4 c.30 n¹291 & 30 & Solutréen supérieur & Os brallé & & L.yon 10353 (SacA 33962) & $19050 \pm 100$ & $23302-22608$ & fig $3 n^{\circ 2}$ \\
\hline CZ 86$] 4$ c.31 n'2049 & 31 & Solutréen supérieur & Os & Diaphyse OTM & Lyon 10354 (SacA 33963) & $19320 \pm 100$ & $23566-22966$ & fig $3 n^{\circ} 4$ \\
\hline
\end{tabular}

As the excavation data had not yet been computerized at that time, it was not possible to systematically project each dated remain. However, in several cases, the planimetric and altimetric proximity with specific lithic objects was observed, such as the percussion flake from 1. 21, located right beside a fragment of a Badegoulian shouldered point (fig. 3, $\mathrm{n}^{\circ} 5$; J4 c.21c $\mathrm{n}^{\circ} 1504$ : the stratigraphic section chosen in fig. $6 \mathrm{~A}$ does not illustrate this spatial relationship). Nonetheless, the projection of all the pieces became possible at a later stage (fig. 6 and 7) and will be the subject of future archaeostratigraphic studies (cf. supra). The computerization of the excavation notebooks resulted in the correction of the stratigraphic origin of one of the dated pieces: the cortical splinter selected from 1.23 (according to its marking; fig. $3, \mathrm{n}^{\circ} 4$ ), turned out to belong to 1.22 (according to excavation notebook data). Although in theory, this reattribution only has a slight impact on the dating strategy (both layers being attributed to the Early Badegoulian), note that 1.22 had been deliberately excluded from the selection process, given its intermediate position between the Early and Recent Badegoulian, but also on account of the presence of several raclettes which are clearly spatially associated with the concentration of raclettes recorded in 1.20 and 21 (fig. 2; Ducasse 2010, p. 230). We will see that these elements of discussion shed light on the possible interpretation of the $14 \mathrm{C}$ results obtained from this sample (cf. infra).

Specifically, note that, in theory, this selection does not allow us to reply to taphonomic questions, including the problem raised by the Solutrean ages obtained in $1 . s 11$ and 16 for example. The decision to only date technical remains linked to antler percussion at Cuzoul de Vers, reflects the resolve to date Badegoulian occupations in so far as the production method generating this type of waste was not recorded in the Solutrean levels (which present, moreover, very little worked antler: Pétillon and Averbouh 2012) ${ }^{13}$. 
Figure 3 - Nature and stratigraphic position of the samples chosen for AMS dating within the Badegoulian sequence $\left(n^{\circ} 1\right.$ : base of shed antler showing knapping marks; $n^{\circ} 2$ to 5 : antler flakes, $\mathrm{n}^{\circ}$ 6: blank splinter). The white rectangles show the sampled areas; note the line of micro drilling holes on sample ${ }^{\circ} 6$.

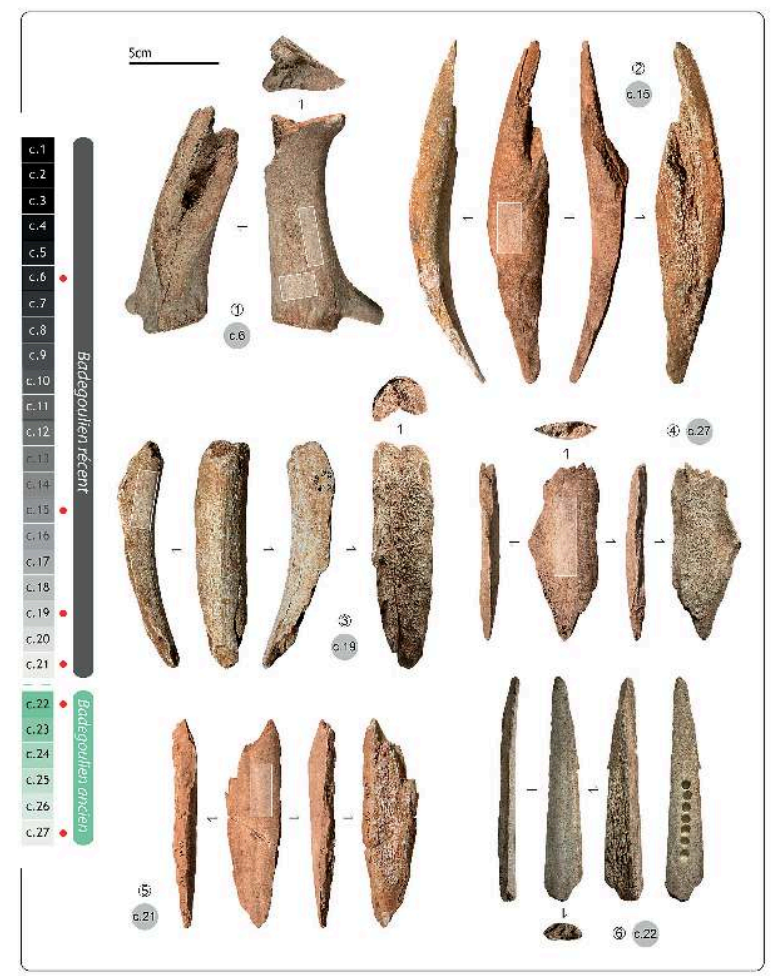

Thus, given the extreme rarity of the Solutrean bone industry, which is, moreover, not very characteristic (Le Guillou 2012; Pétillon and Averbouh 2012), our choice focused in this case on the faunal remains from each of the three layers. This selection was made at the beginning of the year 2013, and thus, unlike the Badegoulian levels, was accompanied by the stratigraphic projection of each selected object, in order to test the hypothesis that these three layers identified during fieldwork may in fact make up a single and coherent layer (Renard 2012) with specific "activity zones" to the east and west of the site. This hypothesis is based on typological and techno-economic observations, on the interpretation of the different refits and associations (cf. fig. 2), but also on "complementary" spatial distribution (Fourment and Giraud 2012, p.409)but apparently contradicted by $14 \mathrm{C}$ data (cf. supra). Four coordinated bone remains were thus selected for dating with the collaboration of Jean-Christophe Castel (fig. 4A), taking account of their position and spatial distribution in relation to each layer (fig. 4B). A reindeer metatarsal (fig. $4 \mathrm{~A}, \mathrm{n}^{\circ} 1$ ) was selected in layer 29 - a layer extending mainly over the east of the rock shelter -, and two remains ( $\mathrm{n}^{\circ} 2$ and 3 ) were taken from layer 30, which corresponds to two disjointed concentrations correlated to two hearths, one to the west of the rock shelter, and the other to the east. The two selected pieces come from each of these concentrations (fig. 4B; a reindeer tibia from 1. 30-east and a medium-sized ungulate shaft fragment from 1. 30-west). The fourth and last object concerned ( $n^{\circ} 4$ : medium-sized ungulate shaft) comes from the base of 1.31 located to the east of the rock shelter and interpreted as the extension of the hearth present in this zone in 1.30 (cf. note 6). 


\section{Sampling methods}

The pieces selected from the three Solutrean layers do not present any major constraints in terms of conservation (i.e., they are not very "sensitive" faunal remains, samples taken directly by the Lyon laboratory), but this is not the case for the Badegoulian elements for which it was important to limit sample destruction. Thus, although the status of these pieces (i.e., reindeer antler débitage waste) differentiates them from finished objects sometimes selected for dating (e. g. Aujoulat et al. 1998; Barandiaran 1988; Chauvière et al. 2006; Pétillon et al. in press; Szmidt et al. 2009; Tisnerat-Laborde, Valladas, Ladier 1997), the sampling methods applied sought to preserve, as much as possible, the morphological, dimensional and technological condition of each remain (fig. 3). This sine qua non condition is respected in order to technologically reexamine the pieces in the future and to critically assess the results and interpretations presented here (even to apply additional radiometric analyses to the same pieces). A specific sampling protocol was thus elaborated before submitting the samples to the laboratory, directly inspired by the procedure developed by Laurent Brou (Brou 2006; Ducasse and Renard dir. 2013, p. 32-34 with several adaptations). After recording the morphometric and technological data and taking photos, each piece was subject to the same series of operations: (1) selection of the best preserved zone (i.e., good thickness of compact tissue, non-fissured zone in order to avoid the fragmentation of the object, absence of visible technical marks); (2) cleaning of the selected zone by abrasion of the outer layer of the object, potentially contaminated (tool used: wood drill with a $3 \mathrm{~mm}$ bit mounted on a mini drill); (3) removal of the material to date by successive micro-drilling (e.g., fig. $\left.3, n^{\circ} 6\right)$ in order to obtain several solid samples with a total mass varying between 450 and $1040 \mathrm{mg}$ depending on the pieces (tools used: drill bit with a diameter of $7 \mathrm{~mm}$, precision scale). These three stages were repeated for each piece, the drill and drill bits were cleaned by ultrasound immersion between each series of samples in order to avoid any possible inter-sample pollution. The seven samples obtained in this way were stored in sterile Eppendorf tubes and then submitted to the dating laboratories.

\section{Results and discussion}

All the samples taken were dated. The 11 results (tab. 2 and fig. 5A) show the same level of precision, with standard deviations ranging between \pm 100 and \pm 110 , whatever the laboratory. Once calibrated, the measurements form a relatively coherent set in comparison to the data acquired in 2001 (fig. 1B, on the right), apart from for the samples from 1.15 - which yield an aberrant age for an, as of yet, unidentified reason (fig. 6D) ${ }^{14}$ - and 1. 30-east, which we will come back to later. For the Badegoulian, this coherence partly results from the implementation of a sampling strategy that does not address taphonomic questions but is adapted to previously defined questions and objectives. In addition, it transcends the double origin of the measurements (tab. 2: Oxford $\mathrm{N}=2$; Lyon/Saclay $\mathrm{N}=5$ ) as dates of the same sample carried out by both laboratories (cf. supra: 1. 6) yielded strictly equivalent results (fig. 5A: $18620 \pm 100 \mathrm{BP}$ and $18660 \pm 100 \mathrm{BP})$. 
Figure 4 - Nature and location of the samples chosen for AMS dating in the Solutrean sequence $\left(\mathrm{n}^{\circ}\right.$ 1: reindeer metatarsal; $n^{\circ} 2$ : burnt reindeer distal tibia epiphysis; $n^{\circ} 3$ : distal shaft from a juvenile medium-sized ungulate; $\mathrm{n}^{\circ} 2$ and 4: photos $\mathrm{J}$.-C. Castel).

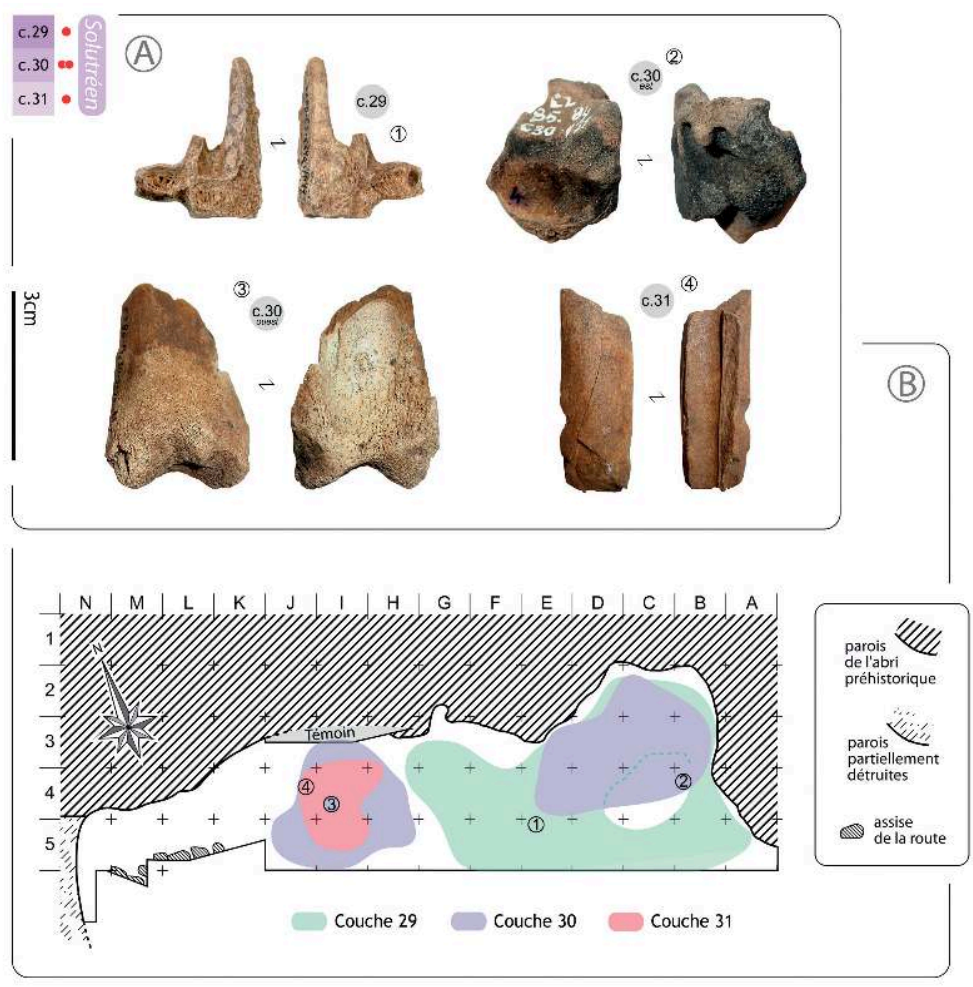

Both these measurements, and the new date obtained for 1.29 (19410 $\pm 100 \mathrm{BP})$, are more or less identical to the results obtained for the same level by the Oxford laboratory in 2001 (tab. 1, nº 8: $18730 \pm 110 \mathrm{BP}, \mathrm{n}^{\circ}$ 19: $19510 \pm 110 \mathrm{BP}$ ).

This first element provides a guarantee of the excellent level of comparability and rules out the "laboratory" factor from any discussion of this new series of dates. These dates can thus be integrated with the previously available AMS corpus. 
Figure 5 - Results of the 2011-2013 AMS radiocarbon dates. A: Summary of the 11 calibrated new dates. Note the similarity between the $14 \mathrm{C}$ measurements made by $0 x$ ford and Lyon/Saclay on the same antler waste (I. 6). B: Comparison with a selection of $14 \mathrm{C}$ dates (AMS) from raclette-yielding assemblages from the French Badegoulian (data from Debout et al. 2012; Pétillon and Ducasse 2012; Primault et al. 2007) and AMS radiocarbon dates from Badegoulian-type assemblages from Central Europe (data from Terberger 2013).
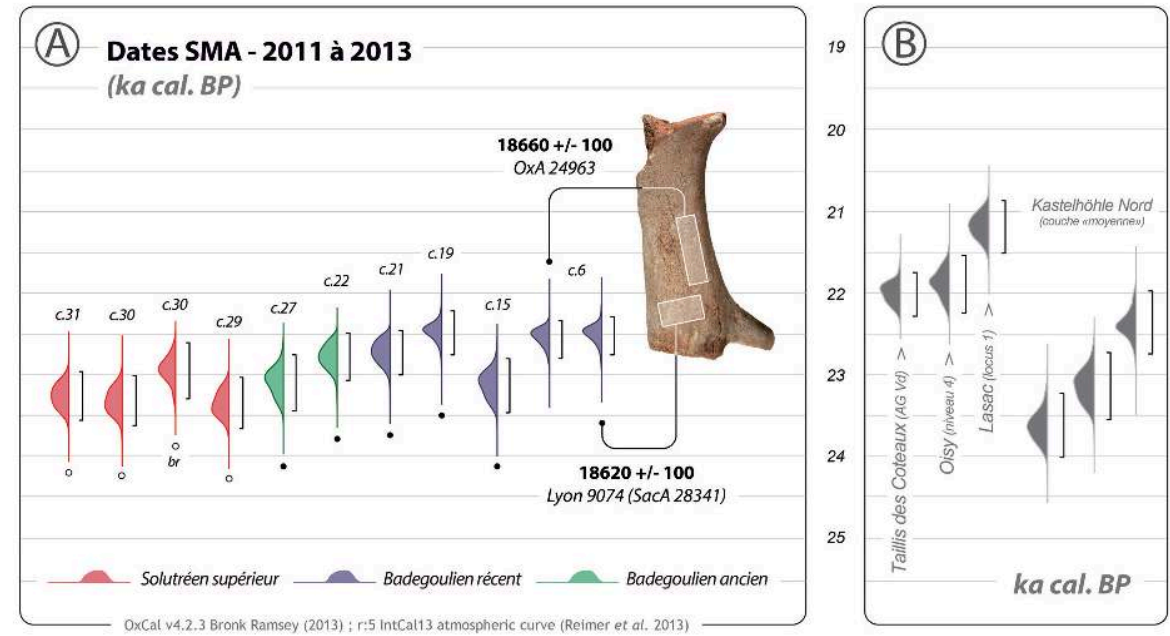

\section{Confirmation and refinement of the AMS framework: The oldest west European Badegoulian}

The main contribution of these new $14 \mathrm{C}$ markers for the Badegoulian sequence is the confirmation of the early age of these occupations and a tightening of the chronology advanced by the first AMS dates. Hence, between 1. 6, which is one of the first real Badegoulian levels (cf. note 7), and 1. 27, which corresponds to the oldest level ascribed to this techno-complex, the total statistical amplitude of the occupations is $\mathbf{1 , 3 0 0}$ years cal. BP (tab. 2: between ca. 23.5 and $22.2 \mathrm{ka} \mathrm{cal} \mathrm{BP}^{15}$ ) compared to 3,800 years cal. BP for classical 14C (tab. 1: 1.s 5 to 24). This thus represents a short time span, and a much older chronology than indicated by the classical $14 \mathrm{C}$ dates. At a regional scale, the date obtained for the Badegoulian level with raclettes at Petit Cloup Barrat is part of a similar chronological bracket (Chauvière et al. 2008; Ducasse et al. 2011), but generally speaking, the available AMS dates for the French Badegoulian ${ }^{16}$ yield more recent ages, mostly between 22.5 and 21 ka cal. BP (fig. 5B; e.g., Debout et al. 2012; Chehmana, Debout, Bodu 2013; Pétillon and Ducasse 2012; Primault et al. 2007; Sacchi, Brulé, Ducasse ed. in press). Pending more AMS dates, the Badegoulian from Cuzoul de Vers is the oldest example of this techno-complex in Western Europe, and is chronologically similar to the Badegoulian type industries documented in Central Europe (fig. 5B; Oberlin and Valladas 2012; Kozlowski et al. 2012; Sedlmeier 2010; Terberger 2013). 
Figure 6 - Stratigraphic projection of the six dated pieces from the Badegoulian levels (frontal sections, every $25 \mathrm{~cm}$ ).

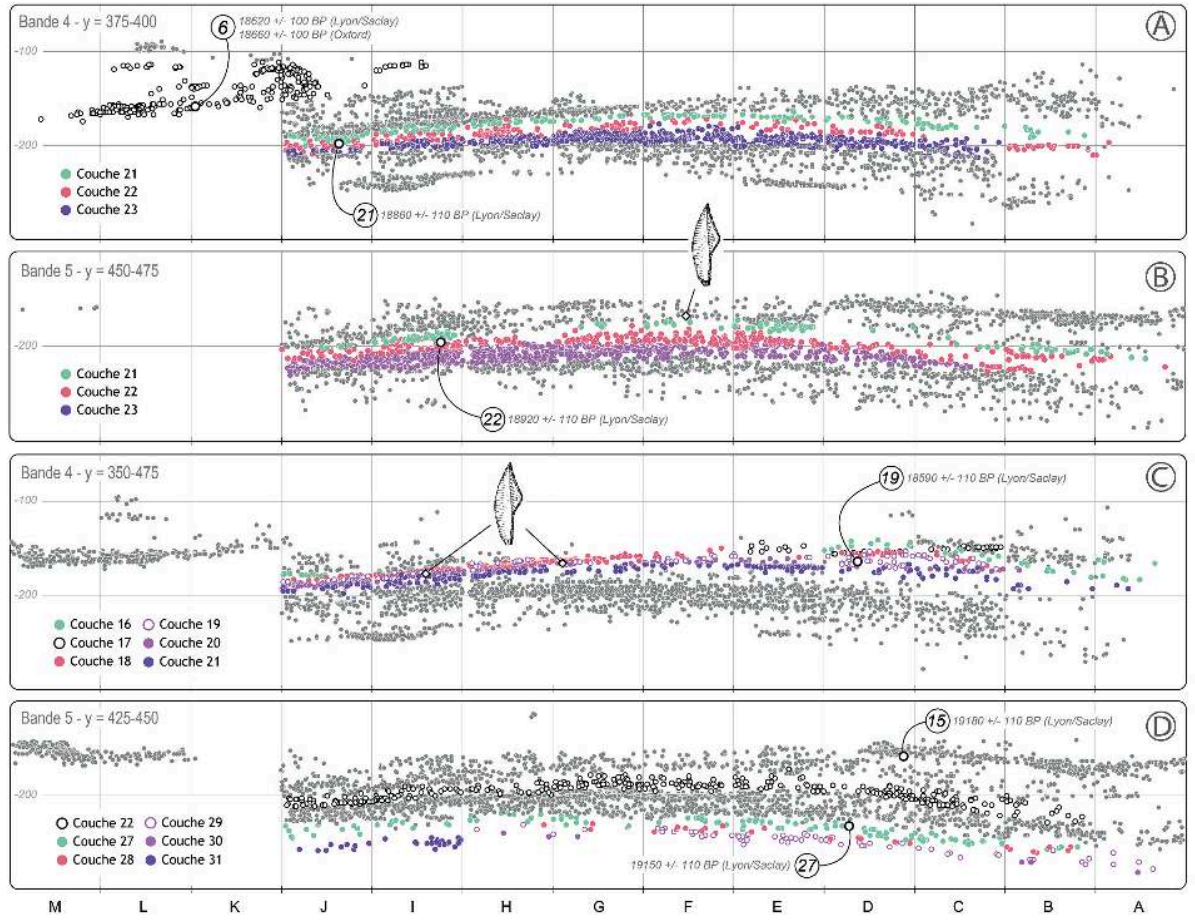

\section{A tighter chronology for the Solutrean levels}

The four dates obtained for the Upper Solutrean (tab. 2) provide important - if not decisive - elements of discussion for this level. They display marked consistency and tend to back up the hypothesis advanced following the techno-economic and taphonomic analysis of the lithic industries (cf. supra), of a short-chronology assemblage linked to a very limited number of occupations (a single and unique occupation?). Three of these dates, from all of the three levels, overlap perfectly (fig. 5A in red), and also echo the AMS date obtained earlier for 1.29 and considered to be the more coherent of the two, after inter-site comparison. Note also, that unlike for the Badegoulian where classical dates and AMS dates are generally discordant (cf. supra), these new dates are perfectly coherent with the classical $14 \mathrm{C}$ measurement obtained for 1.30 (tab. 1: $19400 \pm 210 \mathrm{BP}$ ) although this measurement was made on a bulk sample. It is tempting in this case to see this as another sign of the chronological homogeneity of the 29-30-31 levels, which seems to slot between 23 and $23.5 \mathrm{ka}$ cal. BP. The only discordant note is the measurement obtained for 1.30 , which yielded a much younger age (19050 $\pm 100 \mathrm{BP}$; fig. 7C), and although this date fits well with other dates from regional and extra-regional sites (Hinguant and Biard 2013; Bodu, Dumarçay, Naton 2014; Ducasse and Renard 2014), it is not in keeping with the stratigraphic position of the dated object (fig. 7B; base of the hollow BC3-4: Fourment and Giraud 2012, p. 411). Considering (1) the nature of the dated material, distinct from the three others (tab. 2: burnt bone) and (2) the - partial -insertion of this date in the group formed by the first three once the measurement was calibrated (fig. 5A), the hypothesis of a more recent Solutrean occupation or of a contamination of this level by remains of Badegoulian age must be considered with caution in the absence of concrete evidence. 
Figure 7 - Stratigraphic projection of the four dated pieces from the Solutrean levels (sagittal sections, every 25 or $75 \mathrm{~cm}$ ).
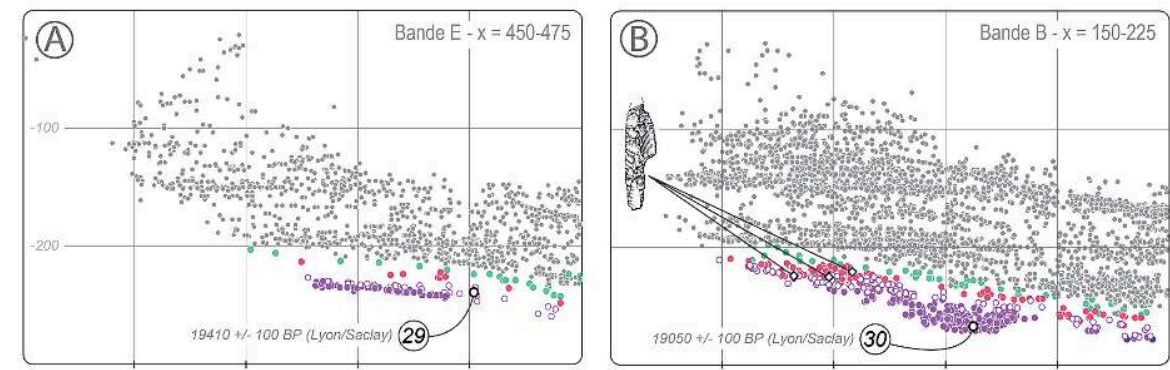

- Couche 31 Couche $30 \quad$ O Couche 29 Couche 28 Couche 27
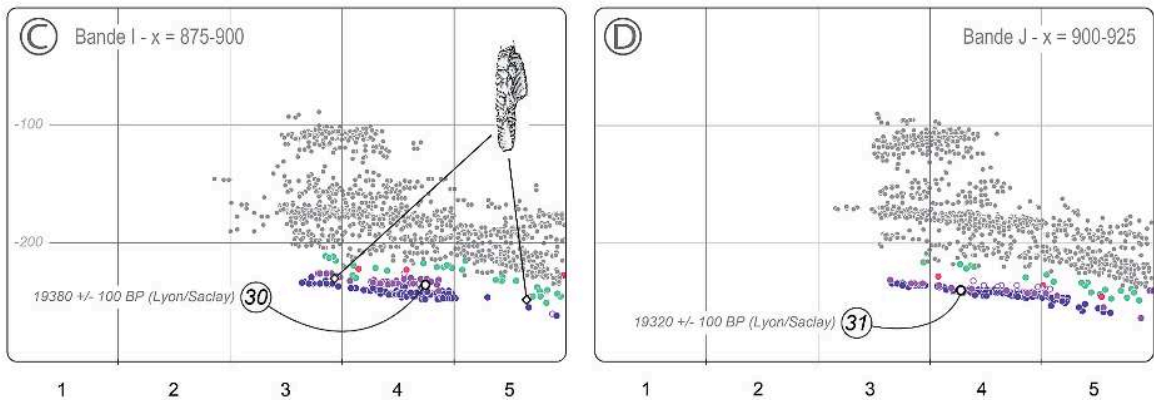

Lastly, note that the date obtained for $1.31(19320 \pm 100 \mathrm{BP})$ for the sample taken from the base of the hearth in J4 (1) invalidates the AMS date for 1. 31 (20110 \pm 180 BP, GifA 101440), attributed to the Solutrean level, and (2) is perfectly in keeping with the date for the sample selected from the overlying 1. 30 in I4 (19380 $\pm 100 \mathrm{BP})$. Although we cannot explain the early age of the date obtained for 1.31 (cf. supra) in 2001 by the Gifsur-Yvette laboratory, note that this new series of measurements tends to further isolate this archaeologically incoherent result.

\section{Diachronic variations of the material and $14 \mathrm{C}$ chronology: what is the degree of resolution?}

We have seen that this tighter chronology for the Cuzoul de Vers sequence involves more or less significant changes in the lithic and osseous material (Clottes, Giraud, Chalard dir. 2012; Ducasse and Renard 2012).

These changes are both typological and techno-economic and are manifest at an intracultural (Early Badegoulian/Recent Badegoulien transition and diachronic variation of the material during the course of the Recent Badegoulian), as well as an intercultural scale (Solutrean/Badegoulian transition). As we have seen, the aim of the renewed radiometric framework is also to obtain $14 \mathrm{C}$ measurements to better document the duration of the different occupation phases as well as their respective limits. 
Given these objectives and the critical analysis of all the available AMS dates for Cuzoul de Vers (cf. supra), we decided to exclude the following elements from the ensuing discussions:

1. the dates obtained from bulk bone samples (l. 6 and 11: tab. $1, \mathrm{n}^{\circ} 9$ and 11) which involve the same sampling methods as the classical dates and which thus present the same biases (possible "average" dates);

2. the measurements that were reliable from a physico-chemical viewpoint, but that gave incoherent, difficult to interpret results (1. 11, 16 and 31: tab. 1, n ${ }^{\circ} 10,13$ and 20; 1.15 from the 2011-2012 series: tab. 2);

3. the measurements with a standard deviation superior to \pm 200 ( \pm 310 for 1.25 and $26, \pm 240$ for 1. 27: tab. $1, \mathrm{n}^{\circ} 16$ to 18 ) which are thus not accurate enough (probabilities spread over about 1500 years cal BP to 2 sigma), and are of no use to the questions raised here.

Fifteen measurements were thus retained out of the 24 AMS dates carried out between 2001 and 2013 for all the levels. Seven dates correspond to the Recent Badegoulian (five layers were dated between 1.6 and 1.21), three dates to the Early Badegoulian (betweeen 1.22 and 1.27) and five dates to the Upper Solutrean (1.29 to 31), so that in theory, the limits of each of these subdivisions have a radiometric marker. Once the two measurements obtained for the same remain from 1. 6 are combined (fig. 8: $18640 \pm 71$ BP; tool "R_Combine" from the OxCal software [version 4.2.3: Bronk Ramsey 2013], used before calibration), the calibration of the 14 dates retained (tab. 3) gives an interval of 23 to $22.3 \mathrm{ka}$ cal. BP for the Recent Badegoulian, whereas the Early Badegoulian extends between 23.5 and $22.5 \mathrm{ka}$ cal. BP. As shown in figure 9, this marked overlap between the Early and Recent Badegoulian is mainly due to the measurement obtained for 1. 22a, which is identical to the date for 1.21. Yet, given (1) the contextual elements presented above for 1.22 and (2) the stratigraphic projection of the dated element which shows its spatial proximity with the first level with raclettes (c.21: fig. 6B), the hypothesis that this measurement dates the base of the Recent Badegoulian appears plausible. Thus, at Cuzoul de Vers, both of the $14 \mathrm{C}$ markers likely to correspond to the industries attributed to the Early Badegoulian place this episode between 23.5 and $23 \mathrm{ka}$ cal. BP. Although the overlap margin between the two Badegoulian phases is considerably reduced by this hypothesis, the Solutrean-Badegoulian transition remains rather nebulous (Oberlin and Valladas 2012). This transition was spared by potential $14 \mathrm{C}$ plateaus since the publication of the IntCal13 curve (Reimer et al. 2013), but is nonetheless characterized by an incompressible radiometric overlap which includes the whole of the Early Badegoulian. If there was an occupation hiatus between the last Solutreans and the first Badegoulians in Aquitaine (e.g., Bosselin and Djindjian 1997; Djindjian 2000; a hypothesis largely based on a corpus of non-calibrated dates obtained by the classical method), then the $14 \mathrm{C}$ method would not appear to be the most effective tool for bringing to light such a phenomenon, if it existed. On the contrary, in spite of the imprecision of the results, these data tend to show not only the early age, but also the relative rapidity of the reconfiguration of techno-economic standards. Finally we note that the Early Badegoulian at Cuzoul de Vers does not seem to last after $23 \mathrm{ka}$ cal. BP, a period when Recent Badegoulian industries with raclettes develop in France (a level that lasts until about 21 ka cal. BP: Langlais et al. 2010; Ducasse 2012; Pétillon and Ducasse 2012). 
Figure 8 - "Combine " and calibration of the two 14C measurements from the same antler waste from I. 6 (OxCal v4.2.: Bronk Ramsey 2013).

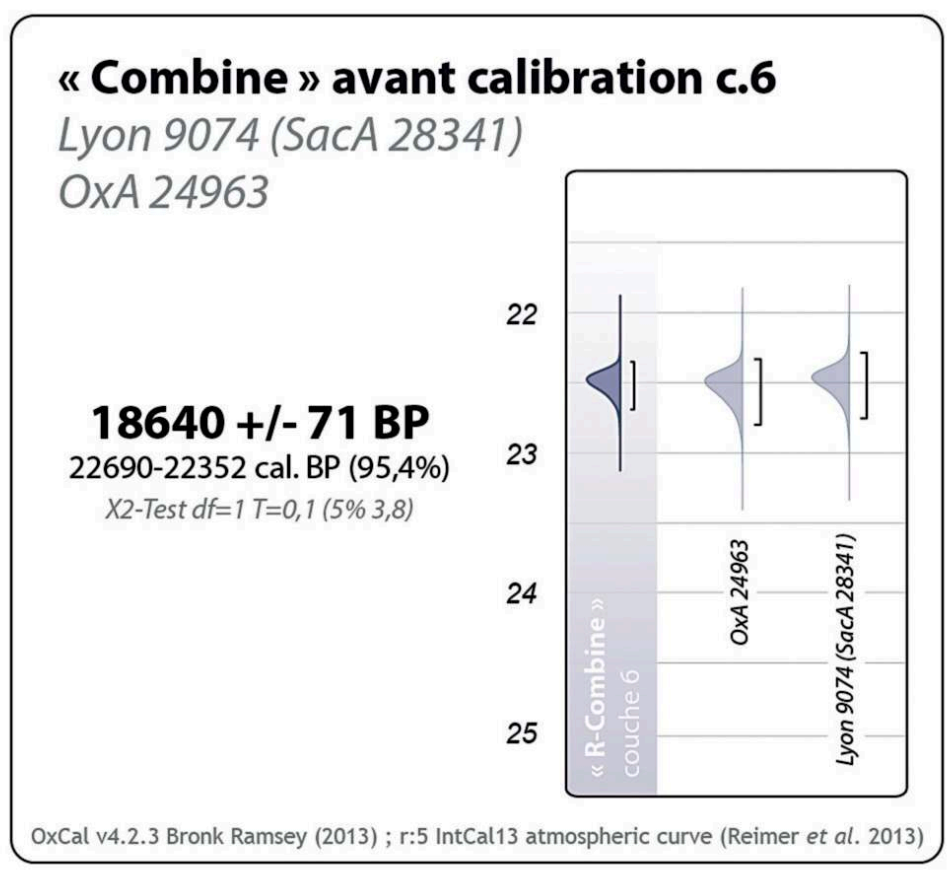

Table 3- AMS dates selected for discussion (BdR = Antler). Calibration was carried out with the OxCal program (v4.2.3: Bronk Ramsey 2013) using the IntCal13 calibration curve (Reimer et al. 2013).

\begin{tabular}{|c|c|c|c|c|c|c|}
\hline Couche & Code laboratoire & Attribution & Matériau & Type d'échantillon & Age BP & Age cal. BP (2б) \\
\hline 6 & $\begin{array}{l}\text { Lyon-9074 (SacA-28341) } \\
\text { et OxA } 24963\end{array}$ & Badegoulien récent & BdR & Base avec négatifs d'éclats & $18640 \pm 71$ & $22690-22352$ \\
\hline 6 & OxA-10955 (Lyon-1674) & Badegoulien récent & Os & Diaphyse OTM & $18730 \pm 110$ & $22889-22383$ \\
\hline 15 & OxA-10974 (Lyon-1676) & Badegoulien récent & Os & Diaphyse ОTM & $18730 \pm 100$ & 22871-22391 \\
\hline 18 & OxA-11118 (Lyon-1681) & Badegoulien récent & Os & Diaphyse OTM & $19020 \pm 110$ & $23262-22555$ \\
\hline 19 & Lyon-9076 (SacA-28343) & Badegoulien récent & $B d R$ & Éclat de percussion & $18590 \pm 110$ & $22757-22216$ \\
\hline 21 & Lyon-9075 (SacA-28342) & Badegoulien récent & BdR & Éclat de percussion & $18860 \pm 110$ & $23003-22460$ \\
\hline $22 \mathrm{a}$ & Lyon-9077 (SacA-28344) & Badegoulien ancien & BdR & Bande corticale & $18920 \pm 110$ & $23072-22489$ \\
\hline $22 \mathrm{~b}$ & OxA-10976 (Lyon-1678) & Badegoulien ancien & Os & Diaphyse OTM & $19280 \pm 120$ & 23563-22901 \\
\hline 27 & Lyon-9078 (SacA-28345) & Badegoulien ancien & $\mathrm{BdR}$ & Éclat de percussion & $19150 \pm 110$ & $23446-22757$ \\
\hline 29 & OxA-11220 (Lyon-1682) & Solutréen supérieur & Os & Diaphyse OTM & $19510 \pm 110$ & 23836-23124 \\
\hline 29 & Lyon-10351 (SacA-33960) & Solutréen supérieur & Os & Métatarsien de renne & $19410 \pm 100$ & $23668-23038$ \\
\hline 30 & Lyon 10352 (SacA 33961) & Solutréen supérieur & Os & Diaphyse OTM & $19380 \pm 100$ & $23631-23016$ \\
\hline 30 & Lyon 10353 (SacA 33962) & Solutréen supérieur & Os brûlé & Tibia de renne & $19050 \pm 100$ & $23302-22608$ \\
\hline 31 & Lyon 10354 (SacA 33963) & Solutréen supérieur & Os & Diaphyse OTM & $19320 \pm 100$ & $23566-22966$ \\
\hline
\end{tabular}

This chronological outline thus confirms that it is essential to refine the meaning of the stratigraphic dilatation of this sequence and the succession of the different sedimentary levels (cf. supra). Thus the narrowing of the $14 \mathrm{C}$ measurements points to a much shorter occupation phase of the rock shelter than previously thought, whereas the different physical links established between some of the layers (fig. 2) allow for the individualization of coherent and significant assemblages from a typological and techno-economic point of view. Nonetheless, the most striking observation remains the extreme similarity between the measurements obtained for the whole of the Recent Badegoulian (from 1. 6 to 1.21: fig. 9). Whereas the proximity of the ages obtained for 1 . 
19 to 21 is in keeping with the typo-technological and taphonomic similarities for 1 . 16-21 (fig. 2: presence of raclettes, shouldered points with abrupt retouch and virtual absence of antler points; lithic refits and associations; Ducasse 2010, p. 30-33, 78 and Ducasse in preparation), their equivalence with the available measurements for the assemblages documented between 1.s 6 and 15 was less predictable, given the differences in hunting equipment (virtual disappearance of lithic arrow heads and development of antler points: fig. 2; Ducasse and Renard 2012, figure 4; Le Guillou 2012). If this radiometric equivalence does not result from confusion and/or difficult to identify stratigraphic disturbances in the absence of systematic refits, the contribution of radiometric data is limited, apart from the fact that they point to the transience of certain occupation episodes and the rapidity of some of these transitions. At an inter-site scale, this predictable distortion of time between the relative chronology and the $14 \mathrm{C}$ chronology probably contributes to maintaining the image of the synchronic diversity of Badegoulian weapons and reminds us, if need be, that this synchrony is often just a "short diachrony" (Boëda 2005).

Figure 9 - Graphic summary of the AMS dates selected for discussion. Calibration was carried out with the OxCal program (v4.2.3: Bronk Ramsey 2013) using the IntCal13 calibration curve (Reimer et al. 2013).

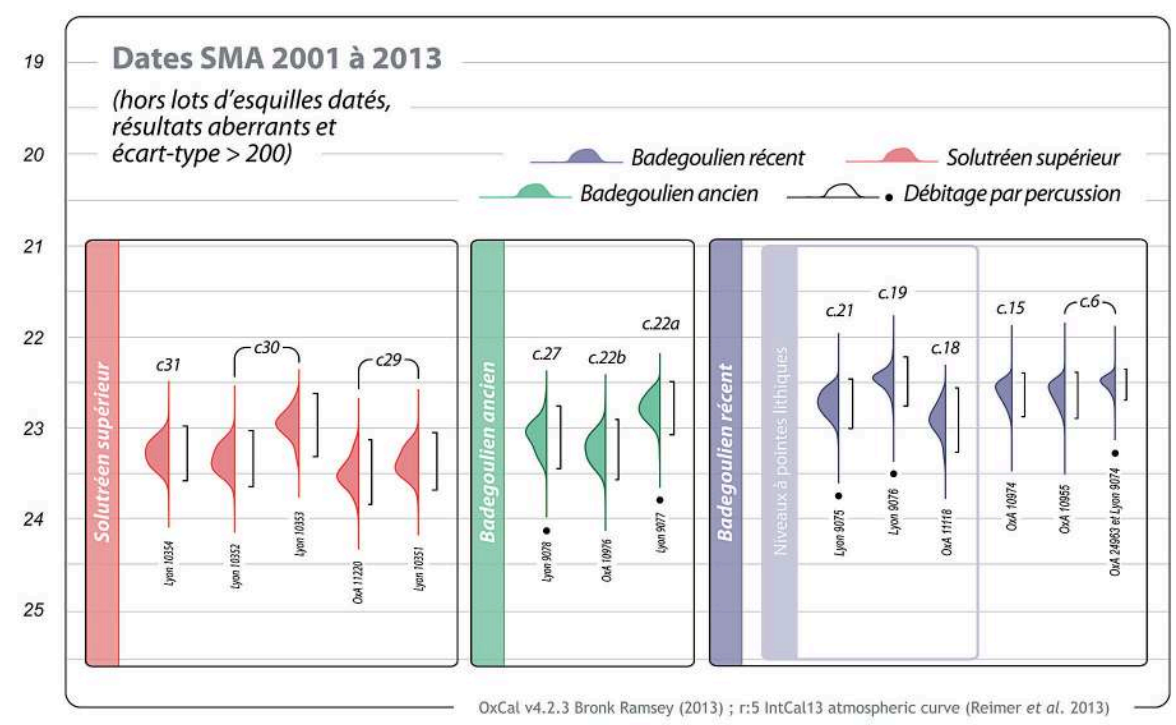

\section{An approach to be extended}

It is important not to grant an excessive role to absolute dates, or to forget their limits and shortcomings, but nonetheless, we must acknowledge the importance of these dates in debates focusing on the evolutionary dynamics of Palaeolithic societies, in the long term (rhythm of evolution, palaeo-climatic and palaeo-environmental correlations) or throughout space (regional divergences of these evolutions, development of cultural "mosaics", etc.). From this point of view, the SolutreanBadgeloulian "transition" appears to be a particularly fertile field of study. This transition is considered as a period of profound reconfiguration of techno and socioeconomic norms (Ducasse 2012; Ducasse and Renard 2012), but its rhythms are still poorly known, thereby limiting the potential understanding of the exact causes and hindering the assessment of its possible diversity throughout south-western Europe. 
The very varied state of the archaeological documentation considerably limits the scope of the different hypotheses and calls for a critical review of the data, zone by zone.

Although the results and interpretations presented here are limited to the site of Cuzoul de Vers, this contribution is part of a reevaluation approach extended to several reference sequences for the LGM in south-western France (SaM Project: Ducasse and Renard (dir.); Morala, Cretin and Ferullo oral com. ${ }^{17}$ ). We are optimistic that this reasoned reappraisal of radiometric frameworks, in conjunction with critical archaeostratigraphic work, and as far as possible, interdisciplinary data pooling, will contribute in the near future to shedding light on certain "blind spots", while pointing out significant tendencies based on controlled and controllable data.

\section{NOTES}

3. The term "classical" is used here to designate the dating method by beta counting as well as any measurement obtained by this method. This allows us to avoid confusion with the expression "conventional dates", which designates any non-calibrated date obtained indifferently by classical methods (i.e. beta counts) or AMS (e.g., Valladas 2002).

4. This study is very advanced for the Solutrean levels (Fourment 2002 according to the refits conducted by C. Renard ; Fourment and Giraud 2012), and the overall archaeostratigraphic analysis of the rich and abundant Badegoulian levels is ongoing, after being suspended while waiting for the computer recording of the excavation data (carried out by two of us - CR and SD and finished in 2013 by A. Angelin as part of the "SaM" collective research project).

5. The date obtained for 1.3 (Gif 6372: $14560 \pm 130 \mathrm{BP}$; batches of bone shards derived from sublevels $3 \mathrm{a}$ and $3 \mathrm{~b}$ ) is considered to be incoherent, given the associated archaeological material (Recent Badegoulian, presence of many raclettes). Nonetheless, it is impossible to say whether this incoherence results from (1) the poor quality of the dated sample, (2) insufficient decontamination or if (3) some of the bone shards from this batch are from a more recent level that was not identified at the excavation (the residual top l.s are only present over very small surfaces). Note that a new test by AMS at the beginning of the 2000s did not yield results due to insufficient collagen (Oberlin and Valladas 2012).

6. As 1.31 is "probably just the very beginning of level 30" (Clottes and Giraud 2012, p. 26).

7. Note that most of the non-dated layers either correspond to residual and sometimes sterile leveles (1. 1, 2 and 4), or to spatially and/or stratigraphically sparse levels $(1.10,12,14)$.

8. In comparison, the base of 1.5 is dated between 19.5 and $18.8 \mathrm{ka}$ cal. BP by classical $14 \mathrm{C}$ whereas 1.6 is dated between 22.2 and $21.3 \mathrm{ka}$ cal. BP by $14 \mathrm{C}$ using AMS.

9. The case of divergent $14 \mathrm{C}$ measurements for the same object dated in two different laboratories is known: see for example Alix et al. 2012 (although in this case, the authors do not have any elements allowing them to interpret this discrepancy).

10. As stated by the authors (Oberlin and Valladas 2012, p. 83), these samples were originally intended for measurements using the classical method in order to test the ageing induced by AMS dating. However, due to their low collagen content, the authors opted for the use of the AMS method once again. 
11. Although the date obtained for 1.25 is not very accurate, it cannot be considered abnormal given its 2 sigma statistic margin (cf. tab. 1 and fig. 1). It is thus of limited interest.

12. As the critical taphonomic review of the Badegoulian sequence is still ongoing, it is important to bear in mind that the data presented in figure 2 are likely to evolve. This explains the absence of the exact quantification of the refits and associations, as such quantification would have limited meaning.

13. Note nonetheless that there are antler flakes in a Solutrean context, but that they could be part of distinct operational chains linked to different production aims (Baumann and Maury 2013; Chauvière et al. 2013). The direct dating of some of these elements in the Grand-Abri de Cabrerets, a Quercy site excavated during the 1950s by A. Lemozi (1961), recently fuelled this debate (Ducasse and Renard dir. 2013, p. 36).

14. (14) Note that this is similar to the incoherent measurement obtained in 1.16 for the first AMS series (fig. 1B), and that the level of precision is equivalent to the other measurements from the 2011-2012 series.

15. Estimated lapse of time based on the lower and upper limits of the confidence intervals obtained for the earliest date (1.27) and the most recent date for the Badegoulian (1.6; tab. 2).

16. Largely carried out by the Lyon laboratory as part of the ARTEMIS program.

17. Morala A., Cretin C., Ferullo O. 2011 - De nouveaux jalons chronologiques pour le Badegoulien aquitain: Bordeneuve and Cassegros. Journée d'étude du laboratoire PACEA, "Les sociétés du Dernier Maximum Glaciaire ouest-européen: Badegoulien et Magdalénien”, June 2011, Bordeaux.

\section{ABSTRACTS}

The pluridisciplinary research carried at Le Cuzoul-de-Vers (Lot, France) over 15 years has been published in late 2012. This publication makes available the data acquired at the end of the 2000s on one of the most important Western European sites for the study of the Last Glacial Maximum (LGM) societies. From this point new interdisciplinary research projects have been built leading to several complements and/or extents. Among them, a reassessment of the radiometric framework due to new AMS ${ }^{14} \mathrm{C}$ dates obtained with the collaboration of Lyon, Saclay and Oxford laboratories is presented here. Eleven new radiocarbon measurements resulting of the direct dating of Badegoulian antler waste products and Solutrean faunal remains whose stratigraphic position has been controlled allow us to specify and/or modify the results previously published. These data tend to confirm (1) the small chronological amplitude of the entire sequence, (2) the old age of the Badegoulian occupations, (3) the very short chronology of the Solutrean levels and (4) the transience of some occupation episodes whose radiometric individualization remains illusory. Led in parallel to an archeostratigraphic analysis in progress (inter-layers refitting), this preliminary work shows the necessity to precisely redefine the assemblages studied. As a collective work, this approach is part a wider program (Collective Research Program "SaM") aiming at a better chronological seriation of the techno- and socio-economic changes documented in the early part of the LGM north of the Pyrenees.

Publiée en fin d'année 2012, la monographie du gisement solutréen et badegoulien du Cuzoul-deVers (Lot) présente l'état d'une recherche pluridisciplinaire menée sur près de 15 ans. Elle rend disponible les données acquises au terme des années 2000 sur l'un des sites ouest-européens les plus importants pour l'étude des sociétés du Dernier Maximum glaciaire. Dans son sillage, de 
véritables approches interdisciplinaires ont vu le jour, approches nourrissant des projets qui dépassent aujourd'hui le cadre de cet ouvrage. Parmi ces compléments et/ou extensions, le présent article propose une relecture critique du cadre radiométrique à la lueur d'une nouvelle série de dates ${ }^{14} \mathrm{C}$ par SMA obtenue avec la collaboration des laboratoires de Lyon, Saclay et Oxford. Résultant de la datation directe de plusieurs déchets de débitage en bois de renne badegouliens et restes fauniques solutréens dont la localisation stratigraphique a été préalablement contrôlée, les 11 nouvelles mesures nous permettent de discuter, de préciser et/ ou de modifier les résultats précédemment publiés. Ces données tendent à confirmer (1) la faible amplitude chronologique de l'ensemble de la séquence du Cuzoul-de-Vers, (2) l'ancienneté des occupations badegouliennes, (3) la chronologie resserrée des niveaux solutréens et (4) la fugacité de certains « épisodes » d'occupation dont l'individualisation s'avère aujourd'hui illusoire sur le plan radiométrique. Accompagnant l'analyse archéostratigraphique aujourd'hui en cours, ce travail préliminaire illustre enfin la nécessité d'une redéfinition précise des ensembles étudiés. Fruit d'un travail collectif, cette démarche est aujourd'hui inscrite dans un programme plus large ( $\mathrm{PCR}$ « SaM ») visant notamment une meilleure sériation temporelle des changements techno- et socio-économiques documentés dans la première moitié du DMG au nord des Pyrénées.

\section{INDEX}

Keywords: Last Glacial Maximum, Recent Solutrean, Badegoulian, Quercy, Le Cuzoul-de-Vers, AMS 14C chronology

Mots-clés: Dernier Maximum Glaciaire, Solutréen récent, Badegoulien, Quercy, Le Cuzoul-deVers, datation $14 \mathrm{C}$

\section{AUTHORS}

\section{SYLVAIN DUCASSE}

CNRS, Laboratoire PACEA (UMR 5199), Université de Bordeaux, Bâtiment B18, Allée Geoffroy StHilaire, CS 50023, FR-33615 Pessac cedex - s.ducasse@pacea.u-bordeaux1.fr

\section{JEAN-MARC PÉTILLON}

CNRS, Laboratoire TRACES (UMR 5608), Maison de la Recherche, Université de Toulouse - Le Mirail, 5 Allées Antonio Machado, FR- 31058 Toulouse cedex 9 - petillon@univ-tlse2.fr caroline.renard@univ-tlse2.fr

\section{CAROLINE RENARD}

CNRS, Laboratoire TRACES (UMR 5608), Maison de la Recherche, Université de Toulouse - Le Mirail, 5 Allées Antonio Machado, FR- 31058 Toulouse cedex 9 - petillon@univ-tlse2.fr caroline.renard@univ-tlse2.fr 